\title{
Modifications induced by dietary lipid source in adipose tissue phospholipid fatty acids and their consequences in lipid mobilization
}

\author{
María P. Portillo ${ }^{1}$, Ana I. Tueros ${ }^{1}$, Javier S. Perona ${ }^{2}$, Valentina Ruiz-Gutiérrez ${ }^{2}$, Isabel Torres ${ }^{1}$ and \\ M. Teresa Macarulla ${ }^{1}$ \\ ${ }^{1}$ Department of Nutrition and Food Science, University of País Vasco, Paseo de la Universidad 7, 01006 Vitoria, Spain \\ ${ }^{2}$ Instituto de la Grasa (C.S.I.C.), Avda Padre García Tejero 4, 41012 Sevilla, Spain
}

(Received 30 October 1998 - Revised 8 April 1999 - Accepted 2 June 1999)

\begin{abstract}
The aim of the present work was to assess the influence of dietary lipid source on fatty acid phospholipid profiles and on lipid mobilization. Forty male Wistar rats were divided into four groups and fed on high-fat diets which provided olive oil, sunflower oil, palm oil or beef tallow. All rats received the same amount of energy to avoid hyperphagia and differences in energy intake among groups. Phospholipid fatty acids were determined by GC. Lipolysis was stimulated in subcutaneous and perirenal isolated adipocytes by several lipolytic agents, and assessed by the determination of released glycerol. After 4 weeks of feeding, differences in body and adipose tissue weights were not observed. Dietary regimens caused great changes in adipose tissue phospholipid composition: rats fed on palm oil and beef tallow had higher concentrations of saturated fatty acids and animals fed on olive oil or sunflower oil had greater amounts of oleic and linoleic acids, respectively. These modifications did not lead to important changes in adipocyte lipolysis. Significant differences were only observed between palm-oil- and beef-tallow-fed groups when lipolysis was stimulated by isoproterenol in subcutaneous adipocytes. The fact that our feeding protocol did not induce differences in fat accumulation among groups avoids misinterpretations due to adiposity changes. The differences observed between both saturatedfat-fed groups, therefore, should only be attributable to dietary lipids. Despite this effect, the data from this work indicate that some diet-induced changes in adipose tissue fatty acid composition may have little effect on overall function.
\end{abstract}

Fatty acids: Adipose tissue: Lipolysis: Phospholipids

The primary role of adipose tissue is to serve as a temporary storage site for energy in the form of triacylglycerol. The regulation of adipose tissue lipolysis, which allows the appropriate delivery of fatty acids to meet the lipid fuel needs of lean tissue, is affected by the amount and the location of fat, as well as by the diet (Jensen, 1998).

Lipolysis is induced when catecholamines bind to $\beta$ adrenergic receptors. This causes a $\mathrm{G}_{\mathrm{s}}$-protein-mediated activation of adenylate cyclase (EC 4.6.1.1) and the consequent production of cyclic AMP. Cyclic AMP activates a protein kinase that, in turn, phosphorylates the hormonesensitive lipase (EC 3.1.1.3). The activation of this enzyme results in hydrolysis of the stored triacylglycerol with the release of glycerol and free fatty acids as end products (Lafontan \& Berlan, 1993).

$\beta$-Adrenoceptors and adenylate cyclase, as well as other integral membrane-bound enzymes, are dependent upon membrane lipid environment (Houslay, 1985; Nicolas et al. 1991). Several studies have suggested that the phospholipid composition of various body tissues is susceptible to modification by varying the composition of dietary fat (Clandinin et al. 1983; Khuu Thi-Dinh et al. 1990; Nicolas et al. 1990; Ruiz Gutiérrez et al. 1990; Pan \& Storlien, 1993; Ayre \& Hulbert, 1996; Suárez et al. 1996).

These modifications may alter the physical properties of membranes, such as fluidity (McMurchie, 1988; Clandinin et al. 1994), and hence a wide range of cellular activities (Murphy, 1990). Such effects have generally been attributed to changes in the levels of unsaturated fatty acids or in the cholesterol:phospholipid ratio of the membranes (Spector \& York, 1985; Murphy, 1990).

The present paper reports a study designed to examine the influence of isoenergetic high-fat diets, providing different lipid sources, on the fatty acid composition of adipocyte membrane phospholipids and to determine whether these effects are reflected in the lipolytic responses of adipose tissue samples from two different anatomical locations. 
Table 1. Composition of experimental diets

\begin{tabular}{|c|c|c|c|c|}
\hline Diet ... & Olive oil & Sunflower oil & Palm oil & Beef tallow \\
\hline \multicolumn{5}{|l|}{ Ingredients $(\mathrm{g} / \mathrm{kg})$ : } \\
\hline Casein* & 200 & 200 & 200 & 200 \\
\hline DL-Methionine & 4 & 4 & 4 & 4 \\
\hline Sucrose & 244 & 244 & 244 & 244 \\
\hline Wheat starch & 245 & 245 & 245 & 245 \\
\hline Olive oil & 200 & - & - & - \\
\hline Sunflower oil & - & 200 & - & - \\
\hline Palm oil & - & - & 200 & - \\
\hline Beef tallow & - & - & - & 200 \\
\hline Cellulose & 50 & 50 & 50 & 50 \\
\hline Mineral mix $†$ & 45 & 45 & 45 & 45 \\
\hline Vitamin mix $\ddagger$ & 10 & 10 & 10 & 10 \\
\hline Choline chloride salt & 2 & 2 & 2 & 2 \\
\hline Total energy (MJ/kg) & $18 \cdot 8$ & $18 \cdot 8$ & $18 \cdot 8$ & $18 \cdot 8$ \\
\hline \multicolumn{5}{|c|}{ Composition by energy (\%): } \\
\hline Protein & $16 \cdot 4$ & $16 \cdot 4$ & $16 \cdot 4$ & $16 \cdot 4$ \\
\hline Lipids & $40 \cdot 1$ & $40 \cdot 1$ & $40 \cdot 1$ & $40 \cdot 1$ \\
\hline Carbohydrates & $43 \cdot 5$ & 43.5 & 43.5 & 43.5 \\
\hline
\end{tabular}

\section{Materials and methods}

\section{Animals, diets and experimental design}

The experiment was conducted on male Wistar rats, purchased from IFFA-Credo (Barcelona, Spain), which were adapted to the room and cage environment $4 \mathrm{~d}$ before the beginning of the protocol. They were housed individually in polycarbonate metabolic cages (Tecniplast, Gazzada, Italy) and maintained in a temperature- $\left(23 \pm 2^{\circ}\right)$ and humidity$(50 \%)$ controlled room with $12 \mathrm{~h}-12 \mathrm{~h}$ light-dark cycle, lights on at 08.00 hours.

When animals ( $n$ 40) reached a body weight of approximately $215 \mathrm{~g}$, they were randomly divided into four groups (n 10 per group), and were fed on diets which provided lipids from different sources for 4 weeks. The spontaneous energy intake of rats showing a similar body weight was calculated in previous studies conducted in our laboratory.
Adequate quantities of experimental diets were offered to rats from experimental groups in order to provide this amount of energy and to avoid a spontaneous energy hyperphagia. All rats had free access to water.

The experimental diets were freshly prepared once weekly, gassed with $\mathrm{N}_{2}$ and stored at $0-4^{\circ}$ to avoid rancidity. The composition of all diets is described in Table 1. The fats used were olive oil, sunflower oil, palm oil and beef tallow; they represented $40 \%$ of total energy. Dietary supply of vitamins, minerals and protein was in good accordance with dietary recommended allowances for rats (National Research Council, 1978; Cunnane, 1996; Cunnane \& Anderson, 1997). The fatty acid composition of the diets was determined by GC and it is shown in Table 2. Total cholesterol content in the diets was measured using a kit purchased from Boehringer Mannheim (Barcelona, Spain). Beef tallow was not supplemented with linoleic acid

Table 2. Fatty acid composition of dietary fats ( $\mathrm{g} / 100 \mathrm{~g}$ total fatty acids) ${ }^{*}$

\begin{tabular}{lrcrr}
\hline Fatty acid & Olive oil & Sunflower oil & Palm Oil & Beef tallow \\
\hline $12: 0$ & $<0.10$ & $<0.10$ & $<0.10$ & 0.20 \\
$14: 0$ & $<0.10$ & 0.10 & 1.21 & 4.89 \\
$14: 1 n-5$ & $<0.10$ & $<0.10$ & $<0.10$ & 0.60 \\
$16: 0$ & 11.87 & 6.13 & 42.93 & 29.33 \\
$16: 1 n-7$ & 0.94 & 0.11 & 0.18 & 2.69 \\
$18: 0$ & 2.92 & 4.60 & 4.25 & 24.21 \\
$18: 1 n-9$ & 72.80 & 24.76 & 38.08 & 33.77 \\
$18: 1 n-7$ & 4.46 & 1.51 & 1.71 & 1.75 \\
$18: 2 n-6$ & 5.69 & 61.74 & 10.29 & 1.91 \\
$18: 3 n-3$ & 0.50 & 0.10 & 0.20 & 0.30 \\
$20: 0$ & 0.39 & 0.29 & 0.29 & $<0.10$ \\
$\Sigma$ Saturates & 15.18 & 11.12 & 48.68 & 58.63 \\
$\Sigma$ Monounsaturates & 78.20 & 26.38 & 39.97 & 38.81 \\
$\Sigma$ Polyunsaturates & 6.19 & 61.84 & 10.49 & 2.21 \\
\hline
\end{tabular}

*Only fatty acids detected at levels greater than $0.10 \mathrm{~g} / 100 \mathrm{~g}$ total fatty acids are listed. 
because the amount of this fatty acid provided by this lipid source allows an adequate supply (National Research Council, 1978). Casein was purchased from Sigma (Barcelona, Spain) and vitamins from Roche (Barcelona, Spain). The dietary oils were obtained from local sources.

At the end of the feeding period, animals were killed by cervical dislocation after an overnight fast. Subcutaneous and perirenal adipose tissues were removed from the carcass and weighed. A portion of each tissue was immediately frozen in liquid $\mathrm{N}_{2}$ and stored at $-80^{\circ}$ for fatty acid composition analysis and another portion of each tissue was immediately used for lipolysis measurements.

\section{Fatty acid composition of dietary lipid sources and adipose tissue phospholipids}

Total lipids from adipose tissues were extracted with chloroform-methanol $(2: 1, \mathrm{v} / \mathrm{v})$ using the method of Folch et al. (1957). Neutral lipids were separated from phospholipids by TLC. Dietary fats and adipose tissue phospholipid fatty acids were saponified by heating for 20 min with $0.2 \mathrm{M}$-sodium methylate at $80^{\circ}$. Fatty acid methyl esters were formed by heating again for $20 \mathrm{~min}$ with $0.61 \mathrm{M}-\mathrm{H}_{2} \mathrm{SO}_{4}$ in anhydrous methanol (Ruiz Gutiérrez et al. 1990). After extraction with hexane, fatty acid methyl esters were analysed in a Hewlett-Packard 5890 series II GC (Hewlett-Packard Co., Avondale, PA, USA) equipped with flame ionization detector and using an Omegawax 320 fused-silica capillary column $(30 \mathrm{~m} \times 0.32 \mathrm{~mm}$ i.d., $0.25 \mu \mathrm{m}$ film). The initial column temperature was $200^{\circ}$, which was held for $10 \mathrm{~min}$, then programmed to change from 200 to $230^{\circ}$ at $2^{\circ}$ per min. The injection and detector temperatures were $250^{\circ}$ and $260^{\circ}$ respectively. The flow-rate of He was $2 \mathrm{ml} / \mathrm{min}$. Individual fatty acid methyl esters were identified by comparison of their retention times with standards. Fatty acid methyl esters for which no standard was available were quantified using calibration tables of relative response ratios constructed according to carbon number using GC-mass spectrometry.

\section{Adipocyte preparation}

Isolated adipocytes were obtained by collagenase digestion of adipose tissue fragments in Krebs-Ringer bicarbonate buffer containing albumin $(3.5 \mathrm{~g} / 100 \mathrm{ml})$ (KRBA) and glucose $(5 \mathrm{mM})$ at $\mathrm{pH} 7.4$ and $37^{\circ}$ under gentle shaking at approximately 60 cycles $/ \mathrm{min}$. At the end of the incubation, the fat cells were filtered through a nylon mesh and washed three times with KRBA to eliminate collagenase. Packed cells were brought to a suitable dilution in KRBA for lipolysis and size determination.

\section{Determination of adipocyte size}

Adipocyte diameters were measured by direct microscopy using a $50 \mu \mathrm{l}$ portion of each isolated fat cell suspension. The insertion of a micrometer disc in a focusing eyepiece placed in the phototube produced a projected caliper scale. Adipocytes were recognized by their spherical shape. The mean adipocyte diameter was calculated from the diameters of 200 cells.

\section{Lipolysis measurements}

Isolated fat cells obtained after collagenase treatment were incubated in $0.5 \mathrm{ml} \mathrm{KRBA}(\mathrm{pH} 7.4$ ) containing glucose $(5 \mathrm{mM})$ at $37^{\circ}$ in polyethylene tubes under an $\mathrm{O}_{2}-\mathrm{CO}_{2}$ $(95: 5, \mathrm{v} / \mathrm{v})$ gas phase with gentle shaking (30 cycles/min) in a water bath. Pharmacological agents were added to the cell suspension just before the beginning of the assay. The $\beta$-adrenergic agonist isoproterenol was added in a range of concentrations $\left(10^{-9}-10^{-4} \mathrm{M}\right)$. For the other drugs, forskolin, dibutyryl-cyclic AMP, and isobutylmethylxanthine, maximal lipolytic concentrations were used. The release of glycerol into the incubation medium was used as an index of lipolysis. After $90 \mathrm{~min}$ incubation, the tubes were placed in an ice bath, and $200 \mu \mathrm{l}$ portions of infranatant fraction were taken for enzymic determination of the glycerol concentration (Wieland, 1957). Total lipid content of the incubated fat cell was measured gravimetrically after organic extraction (Dole \& Meinertz, 1960). Assuming that the lipid content is more than $95 \%$ of the fat cell weight, the number of fat cells that are incubated can be calculated by dividing the total lipid weight by the mean cell weight, which in turn can be calculated by using the mean volume of adipocytes. Adipocyte volumes are obtained from cell diameter, taking into consideration their spherical shape and their lipid density $\left(915 \mathrm{~kg} / \mathrm{m}^{3}\right)$ (Di Girolano et al. 1971). This permits the expression of isoproterenol-induced lipolysis on a per cell basis ( $\mu \mathrm{mol}$ glycerol $/ 10^{6}$ cells).

The concentration of isoproterenol that produced a halfmaximum effect $\left(\mathrm{EC}_{50}\right)$, that represents adrenoceptor sensitivity, was calculated graphically from the individual dose-response curves, and expressed as - $\log (\mathrm{mol} / \mathrm{l})$.

Maximal lipolytic responses to lipolytic agents were expressed as the percentage of stimulation with respect to basal lipolysis, in order to correct possible differences in basal lipolysis rates among animals.

\section{Chemicals}

Bovine serum albumin (fraction V), (-)isoproterenol hydrochloride, forskolin, dibutyryl-cyclic AMP and isobutyl-methylxanthine were purchased from Sigma. Crude collagenase A and other enzymes used for glycerol determination were obtained from Boehringer-Mannheim. All other chemicals were of highest reagent grade available.

\section{Statistical analysis}

Values are presented as means with standard errors of the mean. ANOVA was used to test the significance of differences $(P<0.05)$ among groups with subsequent Duncan's $t$ test for mean comparisons.

\section{Ethical approval}

Institutional approval was obtained for care and use of laboratory animals. 
Table 3. Body weights, adipose tissue weights and adipocyte size of rats fed on the experimental diets for 4 weeks ( $n 10$ per group)*

\begin{tabular}{|c|c|c|c|c|c|}
\hline & \multicolumn{4}{|c|}{ Experimental groups } & \multirow[b]{2}{*}{ Pooled SEM } \\
\hline & Olive oil & Sunflower oil & Palm oil & Beef tallow & \\
\hline $\begin{array}{l}\text { Body weights }(\mathrm{g}) \\
\text { Initial } \\
\text { Final } \\
\text { Gain }\end{array}$ & $\begin{array}{r}215^{a} \\
298^{a} \\
94^{a}\end{array}$ & $\begin{array}{r}215^{\mathrm{a}} \\
309^{\mathrm{a}} \\
95^{\mathrm{a}}\end{array}$ & $\begin{array}{r}215^{\mathrm{a}} \\
308^{\mathrm{a}} \\
93^{\mathrm{a}}\end{array}$ & $\begin{array}{r}216^{a} \\
312^{a} \\
96^{a}\end{array}$ & $\begin{array}{l}2 \\
5 \\
4\end{array}$ \\
\hline $\begin{array}{l}\text { Subcutaneous adipose tissue } \\
\text { Weight }(\mathrm{g}) \\
\text { Adipocyte diameter }(\mu \mathrm{m})\end{array}$ & $\begin{array}{l}10 \cdot 9^{a} \\
57^{a}\end{array}$ & $\begin{array}{l}10 \cdot 8^{\mathrm{a}} \\
58^{\mathrm{a}}\end{array}$ & $\begin{array}{l}11 \cdot 1^{a} \\
64^{\mathrm{b}}\end{array}$ & $\begin{array}{c}9 \cdot 6^{\mathrm{a}} \\
58^{\mathrm{a}}\end{array}$ & $\begin{array}{l}0 \cdot 6 \\
2\end{array}$ \\
\hline $\begin{array}{l}\text { Perirenal adipose tissue } \\
\text { Weight }(\mathrm{g}) \\
\text { Adipocyte diameter }(\mu \mathrm{m})\end{array}$ & $\begin{array}{l}6 \cdot 9^{\mathrm{a}} \\
61^{\mathrm{a}}\end{array}$ & $\begin{array}{c}6 \cdot 8^{\mathrm{a}} \\
59^{\mathrm{a}}\end{array}$ & $\begin{array}{l}7 \cdot 2^{a} \\
66^{a}\end{array}$ & $\begin{array}{l}7 \cdot 1^{a} \\
62^{a}\end{array}$ & $\begin{array}{l}0.4 \\
3\end{array}$ \\
\hline
\end{tabular}

${ }^{a, b}$ Mean values within a row with unlike superscript letters were significantly different $(P<0.05)$.

* For composition of diets see Tables 1 and 2.

\section{Results}

Animals fed on the different experimental diets gained comparable amounts of weight during the experimental period. There were no significant differences in perirenal and subcutaneous adipose tissue weights among groups (Table 3).

The average diameter of adipocytes from rats fed on the palm oil was higher than that of animals fed on the other three lipid sources, in both anatomical locations; however, the difference only reached statistical significance in subcutaneous adipose tissue (Table 3 ).

The fatty acid composition of adipose tissue phospholipids from animals fed on each of the experimental diets is shown in Tables 4 and 5, where the important changes caused by dietary regimens can be observed. Phospholipids paralleled, to some extent, dietary fatty acid profiles. Thus, rats fed on palm oil or beef tallow had higher concentrations of saturated fatty acids. Palmitic acid (16:0) was more abundant in the palm-oil-fed group in both tissues but especially in the subcutaneous depot, and myristic acid (14:0) was more abundant in the beef-tallow-fed group in both tissues. Similarly, animals fed on olive oil had greater contents of oleic acid (18:1n-9) in perirenal tissue and animals fed on sunflower oil had higher levels of linoleic acid (18:2n-6) in both tissues. The increase in 18:2n-6 acid in the sunflower-oil-fed group was accompanied by a decrease in the 18:1n-9 acid content.

Whatever the tissue, linoleic acid (18:2n-6) was the major constituent of the $n-6$ family, followed by arachidonic acid $(20: 4 n-6)$. The main differences between both subcutaneous and perirenal tissues were related to $18: 0,18: 1 n-9$

Table 4. Fatty acid composition ( $\mathrm{g} / 100 \mathrm{~g}$ total fatty acids) of phospholipids from subcutaneous adipose tissue of rats ( $n 10$ per group) fed on the experimental diets for 4 weeks*

\begin{tabular}{|c|c|c|c|c|c|}
\hline \multirow[b]{2}{*}{ Fatty acids } & \multicolumn{4}{|c|}{ Experimental groups } & \multirow[b]{2}{*}{ Pooled SEM } \\
\hline & Olive oil & Sunflower oil & Palm oil & Beef tallow & \\
\hline $14: 0$ & $0.97^{a}$ & $0.82^{a}$ & $0.93^{a}$ & $1.92^{b}$ & 0.06 \\
\hline $14: 1 n-5$ & $0.66^{a}$ & $0.40^{a}$ & $0.28^{a}$ & $1.63^{b}$ & 0.08 \\
\hline $16: 0$ & $20 \cdot 26^{\mathrm{a}}$ & $17 \cdot 15^{\mathrm{a}}$ & $27 \cdot 70^{\mathrm{b}}$ & $21 \cdot 18^{\mathrm{a}}$ & 2.03 \\
\hline $16: 1 n-7$ & $2 \cdot 10^{\mathrm{a}}$ & $1.77^{\mathrm{a}}$ & $1.86^{a}$ & $2.44^{\mathrm{a}}$ & 0.03 \\
\hline $18: 0$ & $10 \cdot 69^{a}$ & $9 \cdot 80^{a}$ & $11 \cdot 30^{\mathrm{a}}$ & $15 \cdot 40^{\mathrm{a}}$ & $1 \cdot 11$ \\
\hline $18: 1 n-9$ & $32 \cdot 67^{\mathrm{a}}$ & $19 \cdot 60^{b}$ & $24 \cdot 42^{a b}$ & $28.25^{\mathrm{a}}$ & 1.87 \\
\hline $18: 1 n-7$ & $3.46^{a}$ & $1.78^{\mathrm{b}}$ & $3.04^{a}$ & $2.83^{\mathrm{a}}$ & 0.13 \\
\hline $18: 2 n-6$ & $17 \cdot 10^{\mathrm{a}}$ & $39 \cdot 19^{b}$ & $18.08^{a}$ & $12 \cdot 22^{c}$ & 0.45 \\
\hline $18: 3 n-3$ & $0.21^{a}$ & $0.14^{\mathrm{a}}$ & $0.22^{\mathrm{a}}$ & $0.13^{a}$ & 0.02 \\
\hline $20: 0$ & $0.50^{a}$ & $0.33^{\mathrm{ab}}$ & $0.66^{a}$ & $0.25^{b}$ & 0.05 \\
\hline $20: 4 n-6$ & $8 \cdot 80^{a}$ & $7 \cdot 27^{\mathrm{a}}$ & $10 \cdot 06^{b}$ & $13.06^{b}$ & 0.60 \\
\hline $22: 5 n-3$ & $0.80^{a}$ & $0.87^{a}$ & $0.72^{a}$ & $0.73^{\mathrm{a}}$ & 0.09 \\
\hline $22: 6 n-3$ & $0 \cdot 17^{\mathrm{a}}$ & $0.36^{b}$ & $0.22^{\mathrm{ab}}$ & $0.24^{\mathrm{ab}}$ & 0.05 \\
\hline$\Sigma$ Saturates & $33.00^{\mathrm{ac}}$ & $28 \cdot 10^{a}$ & $40 \cdot 55^{b}$ & $38.58^{b c}$ & 1.94 \\
\hline$\Sigma$ Monounsaturates & $39.33^{\mathrm{a}}$ & $23.55^{b}$ & $29 \cdot 06^{\mathrm{ab}}$ & $34.64^{\mathrm{a}}$ & $2 \cdot 15$ \\
\hline$\Sigma$ Polyunsaturates & $27 \cdot 24^{a}$ & $47.86^{b}$ & $29 \cdot 41^{\mathrm{a}}$ & $26 \cdot 80^{\mathrm{a}}$ & 1.15 \\
\hline$\Sigma n-3$ & $1 \cdot 18^{a}$ & $1.40^{\mathrm{a}}$ & $1 \cdot 16^{\mathrm{a}}$ & $1 \cdot 10^{\mathrm{a}}$ & 0.08 \\
\hline$\Sigma n-6$ & $25 \cdot 71^{\mathrm{a}}$ & $46 \cdot 46^{\mathrm{b}}$ & $28 \cdot 23^{a b}$ & $25 \cdot 28^{a}$ & 0.52 \\
\hline$P: S$ & $0.84^{a}$ & $1 \cdot 72^{b}$ & $0.79^{a}$ & $0.72^{\mathrm{a}}$ & 0.09 \\
\hline
\end{tabular}


Table 5. Fatty acid composition ( $\mathrm{g} / 100 \mathrm{~g}$ total fatty acids) of phospholipids from perirenal adipose tissue of rats ( $n 10$ per group) fed on the experimental diets*

\begin{tabular}{|c|c|c|c|c|c|}
\hline \multirow[b]{2}{*}{ Fatty acids } & \multicolumn{4}{|c|}{ Experimental groups } & \multirow[b]{2}{*}{ Pooled SEM } \\
\hline & Olive oil & Sunflower oil & Palm oil & Beef tallow & \\
\hline $14: 0$ & $1 \cdot 17^{\mathrm{a}}$ & $0.91^{a}$ & $1.85^{b}$ & $2.48^{c}$ & 0.17 \\
\hline $14: 1 n-5$ & $0.80^{a}$ & $0.50^{a}$ & $0.95^{\mathrm{a}}$ & $2 \cdot 36^{\mathrm{b}}$ & 0.25 \\
\hline $16: 0$ & $18 \cdot 45^{a}$ & $16 \cdot 32^{a}$ & $26.90^{\mathrm{b}}$ & $23 \cdot 60^{\mathrm{b}}$ & 0.76 \\
\hline $16: 1 n-7$ & $2 \cdot 35^{a}$ & $2 \cdot 41^{\mathrm{a}}$ & $2.88^{\mathrm{a}}$ & $5 \cdot 17^{\mathrm{b}}$ & 0.24 \\
\hline $18: 0$ & $7.03^{a}$ & $6 \cdot 71^{a}$ & $6 \cdot 64^{a}$ & $8.86^{a}$ & 0.36 \\
\hline $18: 1 n-9$ & $44 \cdot 18^{a}$ & $20 \cdot 21^{b}$ & $35.80^{c}$ & $37.56^{\mathrm{c}}$ & 1.71 \\
\hline $18: 1 n-7$ & $2.55^{a}$ & $1.58^{\mathrm{b}}$ & $2 \cdot 31^{a}$ & $2.59^{a}$ & 0.11 \\
\hline $18: 2 n-6$ & $17.51^{a}$ & $44.95^{b}$ & $15.63^{\mathrm{a}}$ & $12 \cdot 51^{\mathrm{c}}$ & 0.63 \\
\hline $18: 3 n-3$ & $0.23^{a}$ & $0.21^{a}$ & $0.46^{\mathrm{a}}$ & $0.32^{\mathrm{a}}$ & 0.06 \\
\hline $18: 3 n-6$ & $0.44^{a}$ & $0.40^{\mathrm{a}}$ & $0.91^{b}$ & $0.50^{\mathrm{a}}$ & 0.03 \\
\hline $20: 0$ & $0.76^{\mathrm{a}}$ & $0.40^{\mathrm{a}}$ & $1.93^{b}$ & $0.35^{a}$ & 0.06 \\
\hline $20: 4 n-6$ & $3 \cdot 10^{a}$ & $3.78^{a}$ & $3.47^{a}$ & $3.40^{a}$ & 0.33 \\
\hline $22: 4 n-6$ & $0.34^{a}$ & $0.44^{\mathrm{a}}$ & $0.67^{a}$ & $0.67^{a}$ & $0 \cdot 10$ \\
\hline $22: 6 n-3$ & $0 \cdot 14^{a}$ & $0.32^{a}$ & $0.22^{a}$ & $0.20^{a}$ & 0.04 \\
\hline$\Sigma$ Saturates & $28 \cdot 70^{a}$ & $24 \cdot 26^{a}$ & $37 \cdot 70^{\mathrm{b}}$ & $35 \cdot 70^{b}$ & 1.72 \\
\hline$\Sigma$ Monounsaturates & $49 \cdot 17^{a}$ & $24.92^{b}$ & $41.90^{\mathrm{a}}$ & $46.94^{\mathrm{a}}$ & 1.84 \\
\hline$\Sigma$ Polyunsaturates & $21 \cdot 76^{a}$ & $49 \cdot 90^{\mathrm{b}}$ & $21.06^{a}$ & $17.06^{\mathrm{a}}$ & 1.42 \\
\hline$\sum n-3$ & $0.37^{a}$ & $0.53^{a}$ & $0.68^{\mathrm{a}}$ & $0.52^{\mathrm{a}}$ & 0.06 \\
\hline$\Sigma n-6$ & $21.39^{a}$ & $49.57^{b}$ & $20 \cdot 70^{\mathrm{a}}$ & $17.08^{a}$ & 0.50 \\
\hline$P: S$ & $0.75^{\mathrm{a}}$ & $2.07^{b}$ & $0.54^{\mathrm{ac}}$ & $0.48^{c}$ & 0.08 \\
\hline
\end{tabular}

$P$, polyunsaturated; $S$, saturated

${ }_{a, b, c}$ Mean values within a row with unlike superscript letters were significantly different $(P<0.05)$.

* Only fatty acids detected at levels greater than $0.10 \mathrm{~g} / 100 \mathrm{~g}$ total fatty acids are listed. For composition of diets see Tables 1 and 2.

and 20:4n-6 fatty acid contents. In all groups, the level of oleic acid $(18: 1 n-9)$ was higher in perirenal than in subcutaneous tissue. In contrast, the contents of stearic acid (18:0) and arachidonic acid (20:4n-6) were higher in subcutaneous than in perirenal tissue (see Tables 4 and 5).

Concerning the basal rate of lipolysis it was observed that adipocytes of the palm-oil-fed group released significantly more glycerol than those of rats from the other groups (Table 6).

In an attempt to correlate changes in fatty acid composition of adipocyte membrane phospholipids with changes in lipid mobilization, the effects of several lipolytic agents on the adenylate cyclase cascade were assessed.

Isoproterenol-induced lipolysis $\left(10^{-9}-10^{-4} \mathrm{M}\right)$ is shown in Fig. 1. The mean $\mathrm{EC}_{50}$ values $(-\log (\mathrm{mol} / \mathrm{l}))$ for all experimental groups were in approximately the same range and no differences were found among groups, i.e. subcutaneous adipose tissue (6.49 (SEM 0.25), 6.99 (SEM 0.12), 6.69 (SEM 0.15) and 6.51 (SEM 0.17) for olive-oil, sunflower-oil, palm-oil and beef-tallow-fed groups respectively; $P=0.46$ ), and perirenal adipose tissue (7.17 (SEM $0 \cdot 16), 7 \cdot 05$ (SEM 0.12), $6 \cdot 85$ (SEM 0.12) and 6.80 (SEM 0.13)

Table 6. Basal lipolysis and maximal lipolysis induced by several lipolytic agents in subcutaneous and perirenal adipose tissues from rats ( $n 10$ per group) fed on the experimental diets for 4 weeks*

\begin{tabular}{|c|c|c|c|c|c|}
\hline & \multicolumn{4}{|c|}{ Experimental groups } & \multirow[b]{2}{*}{ Pooled SEM } \\
\hline & Olive oil & Sunflower oil & Palm oil & Beef tallow & \\
\hline \multicolumn{6}{|l|}{ Subcutaneous adipose tissue: } \\
\hline Basal lipolysis ( $\mu \mathrm{mol}$ glycerol $/ 10^{6}$ cells) & $0.34^{a}$ & $0.46^{\mathrm{a}}$ & $0.68^{\mathrm{b}}$ & $0.34^{\mathrm{a}}$ & 0.06 \\
\hline $\begin{array}{l}\text { Maximal lipolysis (\% of basal lipolysis) } \\
\text { Isoproterenol } \\
\text { Forskolin } \\
\text { Dibutyryl-cyclic AMP } \\
\text { Isobutyl-methylxanthine }\end{array}$ & $\begin{array}{l}293^{\mathrm{ab}} \\
191^{\mathrm{a}} \\
220^{\mathrm{a}} \\
185^{\mathrm{a}}\end{array}$ & $\begin{array}{l}294^{\mathrm{ab}} \\
176^{\mathrm{a}} \\
187^{\mathrm{a}} \\
161^{\mathrm{a}}\end{array}$ & $\begin{array}{l}261^{\mathrm{a}} \\
171^{\mathrm{a}} \\
170^{\mathrm{a}} \\
157^{\mathrm{a}}\end{array}$ & $\begin{array}{l}365^{\mathrm{b}} \\
206^{\mathrm{a}} \\
206^{\mathrm{a}} \\
184^{\mathrm{a}}\end{array}$ & $\begin{array}{l}20 \\
15 \\
15 \\
12\end{array}$ \\
\hline \multicolumn{6}{|l|}{ Perirenal adipose tissue: } \\
\hline Basal lipolysis ( $\mu \mathrm{mol}$ glycerol $/ 10^{6}$ cells) & $0 \cdot 33^{a}$ & $0 \cdot 33^{a}$ & $0.47^{b}$ & $0.35^{\mathrm{a}}$ & 0.05 \\
\hline $\begin{array}{l}\text { Maximal lipolysis (\% of basal lipolysis) } \\
\text { Isoproterenol } \\
\text { Forskolin } \\
\text { Dibutyryl-cyclic AMP } \\
\text { Isobutyl-methylxanthine }\end{array}$ & $\begin{array}{l}337^{\mathrm{a}} \\
216^{\mathrm{a}} \\
223^{\mathrm{a}} \\
179^{\mathrm{a}}\end{array}$ & $\begin{array}{l}352^{a} \\
239^{a} \\
239^{a} \\
194^{a}\end{array}$ & $\begin{array}{l}355^{a} \\
233^{a} \\
229^{a} \\
187^{a}\end{array}$ & $\begin{array}{l}406^{a} \\
241^{a} \\
271^{a} \\
198^{a}\end{array}$ & $\begin{array}{l}26 \\
22 \\
24 \\
16\end{array}$ \\
\hline
\end{tabular}

\footnotetext{
a,b Mean values within a row with unlike superscript letters were significantly different $(P<0.05)$.
}

${ }^{*}$ For composition of diets see Tables 1 and 2. 

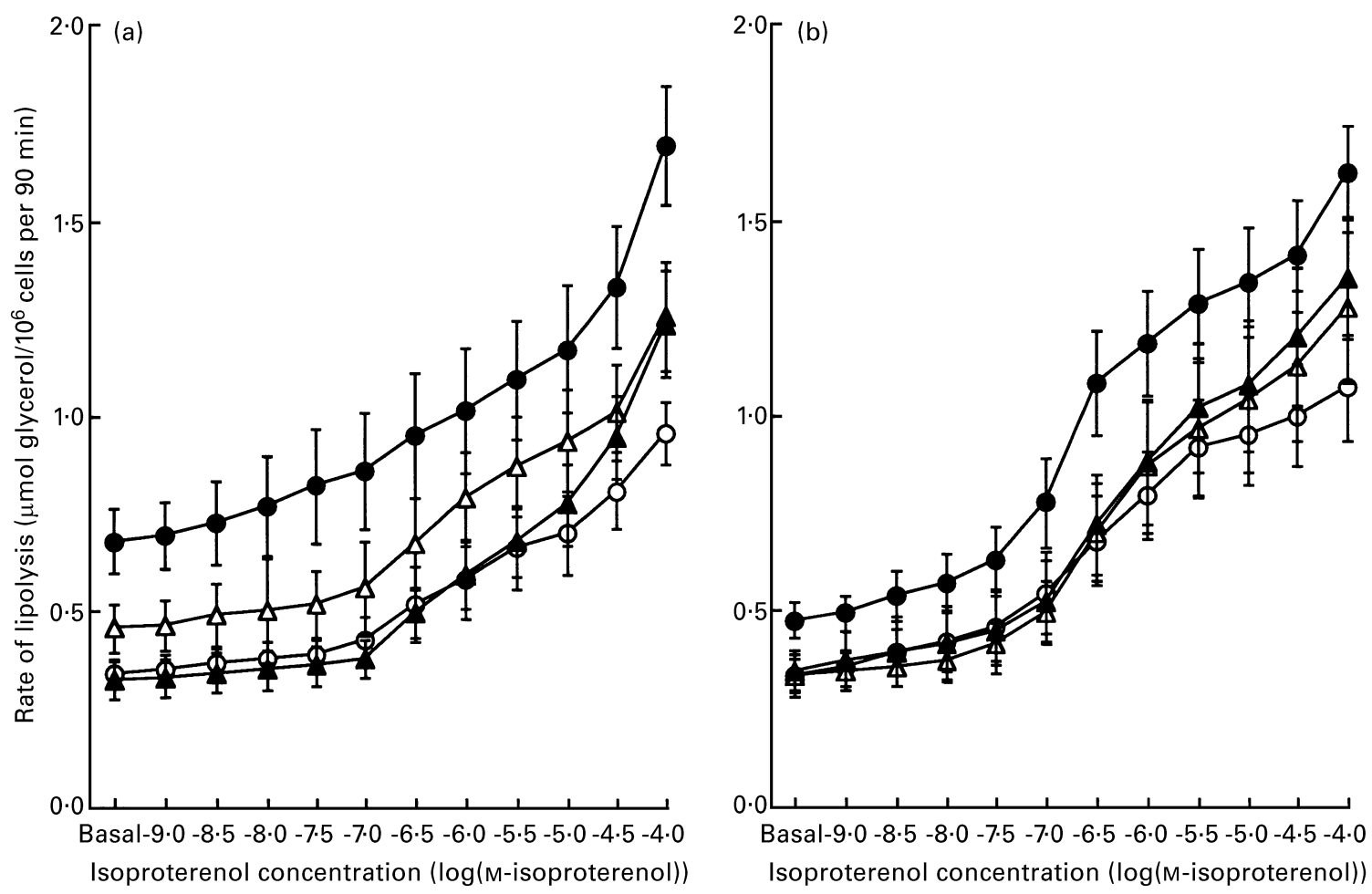

Fig. 1. Dose-response curves for isoproterenol-induced lipolysis in (a) subcutaneous and (b) perirenal adipose tissue from rats $(n 10$ per group) fed on olive-oil $(O)$, sunflower-oil $(\Delta)$, palm-oil $(\mathbf{\bullet})$ or beef-tallow $(\boldsymbol{\Lambda})$ diets for 4 weeks. For details of composition of diets see Tables 1 and 2 . Values are means with their standard errors represented by vertical bars.

for olive-oil, sunflower-oil, palm-oil and beef-tallow-fed groups respectively; $P=0 \cdot 70$ ). Since basal lipolysis was higher in rats fed on the palm oil, the maximal effect in the dose-response curves observed in this dietary group was also higher than those shown by the other groups. Because of this, maximal responses to each lipolytic agent were expressed as the percentage of stimulation of basal lipolysis.

By studying isoproterenol-induced lipolysis, the influence of diet on the lipolytic cascade at the level of $\beta$-adrenoceptors can be assessed. In order to obtain more information concerning lipolytic capacity at levels distal to the $\beta$-adrenoceptors, different agents were used at their maximal lipolytic concentrations: forskolin $\left(10^{-5} \mathrm{M}\right)$ directly activates adenylate cyclase, dibutyryl-cyclic $\operatorname{AMP}\left(10^{-3} \mathrm{M}\right)$ is a stimulator of protein kinase and hormone sensitive lipase, as well as cyclic AMP, but is resistant to the phosphodiesterase (EC 3.1.4.17) activity, and isobutyl-methylxanthine $\left(10^{-5} \mathrm{M}\right)$ is an inhibitor of phosphodiesterase.

Maximal responses to the mentioned lipolytic agents, expressed as the percentage of basal lipolysis, are shown in Table 6. No differences were found among the four experimental groups with the exception of the maximal lipolysis induced by isoproterenol in subcutaneous adipose tissue. In this case, the responsiveness in the beef-tallow group was significantly higher than that of the palm-oil group.

\section{Discussion}

The present work was conducted to study the effects of dietary lipid source on fat accumulation in white adipose tissue, focusing on its possible influence on lipid mobilization. Another point of interest of this study, therefore, was to assess if the previously mentioned possible modifications in lipomobilization have any relationship to changes in the fatty acid profile of plasma membrane phospholipids.

Because lipolytic activity and adrenergic function may differ between subcutaneous adipose tissue and intraabdominal adipose tissues (Faust et al. 1978; Belzung et al. 1993; Hill et al. 1993; Carraro et al. 1994; Sztalryd \& Kraemer, 1994), different effects of dietary treatments in adipose tissues from different anatomical locations can not be disregarded. Thus, perirenal fat pad, as representative of intra-abdominal adipose tissues, and subcutaneous depot were chosen for this study.

The results of the present study showed no differences among groups in final body weight and adipose tissue weights. The results are in good accordance with those published by Awad et al. (1990), who found that 4 weeks of feeding diets containing $32 \%$ energy either as sunflower oil or beef tallow produced no differences in body weight and body composition. In contrast, other authors such as Shimomura et al. (1990) reported that 4 months of feeding diets containing $45 \%$ energy as sunflower oil produced less body fat accumulation than beef-tallow feeding in rats. The discrepancies can be explained by differences in some important variables such as the age of animals, the overall level of fat in the diet, the feeding protocol (ad libitum or energy-controlled feeding pattern) and the duration of the feeding period (Parrish et al. 1991).

Concerning cell size, it was observed that palm-oil 
feeding resulted in an enlargement of adipocytes in contrast with rats fed on the other dietary fats. This effect only attained statistical significance in the subcutaneous depot.

On the other hand, dietary fatty acids had a great effect on the phospholipid fatty acid composition in both subcutaneous and perirenal adipose tissues. As expected, the proportions of fatty acids in phospholipids reflected, to some extent, their concentration in dietary rats (Ruiz Gutiérrez et al. 1990; Camara et al. 1996). The proportions of palmitoleic (16:1n7) and stearic (18:0) acids were higher in adipose tissue than in dietary fats, except for the beef-tallow fed group. This could indicate that part of these fatty acids was probably synthesized de novo or by elongation from fatty acids provided by the dietary fats (Camara et al. 1996).

It is also relevant to point out that the increase in the linoleic acid content (18:2n-6) occurred at the expense of the monounsaturated fatty acid content $(18: 1 n-9$ in particular) in animals fed on sunflower oil. Actually, these rats showed a lower content of oleic acid than rats from the other three groups. This could be attributed to the high oleic content of the other diets as well as to a lower $\Delta^{9}$-desaturase activity in the sunflower-oil group. In this context, it has been reported that an excess of $n-6$ polyunsaturated fatty acid could reduce the synthesis of 18:1n-9 (Momchilova et al. 1985). Buller et al. (1986) demonstrated that $\Delta^{9}$-desaturase might be inhibited by an excess of linoleyl-CoA which is a metabolic derivative of linoleic acid.

Several studies propose that the lipid composition of membranes, and hence their physical properties, particularly the fluidity, can influence the functionality of the $\beta$-adrenergic/ adenylate-cyclase system responsible for lipid mobilization (Houslay, 1985; McMurchie, 1988; Nicolas et al. 1991).

Basal lipolysis was higher in animals fed on the palm oil than in the other three groups whatever the anatomical location (subcutaneous and perirenal). This variable seems, therefore, to be affected by the diet. Since basal lipid mobilization was found to be positively correlated with fat cell size (Hartman et al. 1971; Zinder \& Saphiro, 1971), the increases in adipocyte diameter and basal lipolysis shown by rats from the palm-oil group are concordant.

A greater membrane fluidity could be supposed in sunflower-oil fed rats because the polyunsaturated: saturated fatty acid ratio was increased in both subcutaneous and perirenal adipose tissues due to the accumulation of 18:2n-6. Maximal isoproterenol-stimulated lipolytic response in rats fed on sunflower oil was similar to those of the other three groups in subcutaneous and perirenal adipose tissues. This suggests that the putative increase in membrane fluidity did not lead to changes in functional response. Nevertheless, this suggestion should be made with caution because phospholipid fatty acid composition was analysed, not in isolated adipocytes, but in adipose tissue. A different fatty acid metabolism in blood cells, endothelial cells and preadipocytes can not be excluded.

Other lipolytic agents were also used in order to obtain more detailed information concerning the possible sites of influence for dietary fats, as described in the materials and methods section (pp. 320-321). When lipolysis was induced by those agents, similar responses were found in all groups, indicating that the activities of enzymes involved in the adenylate-cyclase cascade were not affected by the membrane modifications induced by the diets.

The literature provides controversial results concerning the influence of saturated and unsaturated lipids on the lipolytic process (Awad \& Chattopadhyay, 1986a,b; Awad et al. 1990; Parrish et al. 1991; Hill et al. 1992; Mersmann et al. 1992; Su \& Jones, 1993; Matsuo et al. 1995), but in most of the studies, animals fed on unsaturated-fat-enriched diets showed higher lipolytic rates than animals fed on saturatedfat-enriched diets. It is important to point out that these studies were performed by feeding animals ad libitum. Under those conditions, an energy hyperphagia is induced (Faust et al. 1978; Flatt, 1987; Hill et al. 1992; Portillo et al. 1998), and hence overweight or obesity develops. The effects on lipid mobilization, therefore, could be the result of increased adipose mass and dietary fat.

An original aspect of the present study is that rats were not allowed free access to food. Our interest focused on the effects of dietary fatty acids on lipid mobilization in a situation of normal energy intake. On the other hand, it was considered necessary to avoid possible differences in food consumption induced by dietary lipid palatability in order to be sure that the observed effects were attributable to fatty acid composition of the diets but not to a different energy intake. This feeding protocol did not induce changes in adipose tissue mass. This is a point of interest because it avoids misinterpretations due to the adiposity changes and it may explain the discrepancies between our results and those of other authors.

An interesting observation made in the present study was that differences between the two saturated-fat-enriched diets were observed. Feeding beef tallow resulted in a greater isoproterenol-induced lipid mobilization from subcutaneous adipose tissue than feeding palm oil. In the perirenal adipose depot the difference was shown only as a tendency, but it did not reach statistical significance. These differences should only be attributable to dietary lipids because palm oil and beef tallow did not promote different fat accumulation levels.

The explanation for this observation is not clear. Some arguments could be proposed in order to explain our results. Although in both groups the percentage of total saturated fatty acids in subcutaneous adipose tissue phospholipids was similar, perhaps the different proportions of 14:0 and 16:0 fatty acids present in these groups could be involved in the change observed in lipolytic response (16:0/14:0 ratio was 30 in the palm-oil-fed group and 11 in the beef-tallowfed group for subcutaneous adipose tissue). On the other hand, other changes in membrane composition, like modifications in the concentrations of phosphatidylcholine, phosphatidylethanolamine, sphingomyelin and cholesterol could take place. These potential changes could influence physical characteristics of the adipocyte plasma membrane (Spector \& York, 1989; Khuu Thi-Dinh et al. 1990; Nicolas et al. 1990).

In this study we did not measure membrane cholesterol content and distribution of phospholipid classes (phosphatidylcholine and phosphatidylethanolamine). However, since cholesterol contents in the beef tallow and palm oil used were 890 and $0 \mathrm{mg} / \mathrm{kg}$ respectively, cholesterol content of adipocyte membrane must have been higher in the 
beef-tallow group than in the palm-oil group. In this context McMurchie et al. (1987) observed that the increase in membrane cholesterol leads to an increase in cholesterol :phospholipid ratio, which is associated with a higher catecholamine-stimulated adenylate cyclase activity, and Houslay et al. (1985) proposed that cholesterol optimizes the functioning of adenylate cyclase.

Finally, the pattern of response was not exactly the same in both anatomical locations. It may be assumed that the subcutaneous depot was more sensitive than the perirenal depot to the effects of dietary fat, because some of the modifications described earlier (adipocyte size and isoproterenolinduced lipolysis) only reached statistical significance for isoproterenol-induced lipolysis.

In conclusion, the present study suggests that under an energy-controlled feeding pattern, some diet-induced changes in adipose tissue fatty acid composition may have little effect on overall function. It is difficult to attribute the observed effects to a particular fatty acid because each dietary fat provides a mixture of different fatty acids. In order to solve this problem, it would be necessary to enrich the experimental diets with a specific fatty acid.

\section{Acknowledgement}

This study was supported by a grant from the Government of the País Vasco (PI 96/22).

\section{References}

Awad AB, Bernardis LL \& Fink CS (1990) Failure to demonstrate an effect of dietary fatty acid composition on body weight, body composition and parameters of lipid metabolism in mature rats. Journal of Nutrition 120, 1277-1282.

Awad AB \& Chattopadhyay JP (1986a) Effect of dietary saturated fatty acids on hormone-sensitive lipolysis in rat adipocytes. Journal of Nutrition 116, 1088-1094.

Awad AB \& Chattopadhyay JP (1986b) Effect of dietary saturated fatty acids on intracellular free fatty acids and kinetic properties of hormone-sensitive lipase of rat adipocytes. Journal of Nutrition 116, 1095-1100.

Ayre JK \& Hulbert AJ (1996) Dietary fatty acid profile influences the composition of skeletal muscle phospholipids in rats. Journal of Nutrition 126, 653-662.

Belzung F, Raclot T \& Groscolas R (1993) Fish oil $n-3$ fatty acids selectively limit hypertrophy of abdominal fat depots in growing rats fed high-fat diets. American Journal of Physiology 264, R1111-R1118.

Buller KJ \& Enser M (1986) The effects of food intake and dietary fatty acids on the activity of staroyl-CoA $\Delta 9$-desaturase in pig adipose tissue. Journal of Agricultural Science, Cambridge 106, 601-609.

Camara M, Mourot J \& Février C (1996) Influence of two dietary fats on lipid synthesis in the pig: comparative study of liver, muscle and two back fat layers. Annals of Nutrition and Metabolism 40, 287-295.

Carraro R, Li Z \& Gregerman RI (1994) Catecholamine-sensitive lipolysis in the rat: different loci for effect of age on the lipolytic cascade in epididymal $v s$ perirenal fat cells. Journal of Gerontology 49, B140-B143.

Clandinin MT, Foot M \& Robson L (1983) Plasma membrane: can its structure and function be modulated by dietary fat? Comparative Biochemistry and Physiology 76B, 335-339.

Clandinin MT, Jumpsen J \& Suh M (1994) Relationship between fatty acid accretion, membrane composition, and biological functions. Journal of Pediatrics 125, S25-S32.

Cunnane SC (1996) Recent studies on the synthesis, beta-oxidation and deficiency of linoleate and alpha-linoleate: Are essential fatty acids aptly named indispensable or conditionally dispensable fatty acids? Canadian Journal of Physiology and Pharmacology 74, 629-639.

Cunnane SC \& Anderson MJ (1997) Pure linoleate deficiency in the rat: influence on growth, accumulation of $n-6$ polyunsaturates and $\left[1-{ }^{14} \mathrm{C}\right]$ linoleate oxidation. Journal of Lipid Research 38, 805-812.

Di Girolamo M, Mendlinger S \& Fertig JW (1971) A simple method to determine fat cell size and number in four mammalian species. American Journal of Physiology 221, 850-858.

Dole VP \& Meinertz H (1960) Microdetermination of long chain fatty acids in plasma and tissues. Journal of Biological Chemistry 235, 2595-2599.

Faust IM, Johnson PR, Stern JS \& Hirsch J (1978) Diet-induced adipocyte number increase in adult rats: a new model of obesity. American Journal of Physiology 235, E279-E286.

Flatt JP (1987) The difference in the storage capacities for carbohydrate and for fat, and its implications in the regulation of body weight. Annals of the New York Academy of Sciences 499, 104-123.

Folch J, Lees M \& Sloane Stanley GH (1957) A simple method for the isolation and purification of total lipides from animal tissues. Journal of Biological Chemistry 226, 497-509.

Hartman AD, Cohen AI, Richane CJ \& Hsu T (1971) Lipolytic response and adenylate cyclase activity of rat adipocytes as related to cell size. Journal of Lipid Research 12, 498-505.

Hill JO, Lin D, Yakubu F \& Peters JC (1992) Development of dietary obesity in rats: influence of amount and composition of dietary fat. International Journal of Obesity 16, 321-333.

Hill JO, Peters JC, Lin D, Yakubu F, Greene H \& Swift L (1993) Lipid accumulation and body fat distribution is influenced by type of dietary fat fed to rats. International Journal of Obesity 17, 223-236.

Houslay MD (1985) Regulation of adenylate cyclase (EC 4.6.1.1) activity by its lipid environment. Proceedings of the Nutrition Society 44, 157-165.

Jensen MD (1998) Diet effects on fatty acid metabolism in lean and obese humans. American Journal of Clinical Nutrition 67, Suppl. 3, 531S-534S.

Khuu Thi-Dinh KL, Demarne Y, Nicolas C \& Lhuillery C (1990) Effect of dietary fat on phospholipid class distribution and fatty acid composition in rat fat cell plasma membrane. Lipids $\mathbf{2 5}$, 278-283.

Lafontan M \& Berlan M (1993) Fat adrenergic receptor and the control of white and brown fat cell function. Journal of Lipid Research 34, 1057-1092.

McMurchie EJ (1988) Dietary lipids and the regulation of membrane fluidity and function. In Physiological Regulation of Membrane Fluidity, pp. 189-237 [RC Aloia, editor]. New York, NY: Alan R. Liss.

McMurchie EJ, Pattern GS, Charrock JS \& McLennan PL (1987) The interaction of dietary fatty acid and cholesterol on catecholamine-induced adenylate-cyclase activity in the rat heart. Biochimica et Biophysica Acta 898, 137-153.

Matsuo T, Sumida H \& Suzuki M (1995) Beef tallow diet decreases $\beta$-adrenergic receptor binding and lipolytic activities in different adipose tissues of rat. Metabolism 44, 1271-1277.

Mersmann HJ, McNeel RL, Morkeberg JC, Shparber A \& Hachey DL (1992) $\beta$-adrenergic receptor-mediated functions in porcine adipose tissue are not affected differently by saturated vs unsaturated dietary fats. Journal of Nutrition 122, 1952-1959.

Momchilova A, Petkova D, Mechev I, Dimotrov G \& Koumanov K (1985) Sensitivity of $5^{\prime}$-nucleotidase and phopholipase $A_{2}$ 
towards liver plasma membrane modifications. International Journal of Biochemistry 17, 787-792.

Murphy MG (1990) Dietary fatty acids and membrane protein function. Journal of Nutritional Biochemistry 1, 68-79.

National Research Council (1978) Nutrient Requirements of Laboratory Animals. Washington, DC: National Academy of Sciences.

Nicolas C, Demarne Y, Lecourtier MJ \& Lhuillery C (1990) Specific alterations in different adipose tissues of pigs adipocyte plasma membrane structure by dietary lipids. International Journal of Obesity 14, 537-549.

Nicolas C, Lacasa D, Giudicelli Y, Demarne Y, Agli B, Lecourtier MJ \& Lhuillery C (1991) Dietary (n-6) polyunsaturated fatty acids affect $\beta$-adrenergic receptor binding and adenylate cyclase activity in pig adipocyte plasma membrane. Journal of Nutrition 121, 1179-1186.

Pan DA \& Storlien LH (1993) Dietary lipid profile is a determinant of tissue phospholipid fatty acid composition and rate of weight gain in rats. Journal of Nutrition 123, 512-519.

Parrish CC, Pathy DA, Parkes JG \& Angel A (1991) Dietary fish oils modify adipose structure and function. Journal of Cell Physiology 148, 493-502.

Portillo MP, Serra F, Simón E, Del Barrio AS \& Palou A (1998) Energy restriction with high-fat diet gives higher $\mathrm{UCP}_{1}$ and lower white fat in rats. International Journal of Obesity 22 , 974-979.
Ruiz Gutiérrez V, Molina MT \& Vázquez CM (1990) Comparative effects of feeding different fats on fatty acid composition of major individual phospholipids of rat hearts. Annals of Nutrition and Metabolism 34, 350-358.

Shimomura Y, Tamura T \& Suzuki M (1990) Less body fat accumulation in rats fed a safflower oil diet than in rats fed a beef tallow diet. Journal of Nutrition 120, 1291-1296.

Spector AA \& York MA (1985) Membrane lipid composition and cellular function. Journal of Lipid Research 26, 1015-1035.

Su W \& Jones PJH (1993) Dietary fat acid composition influences energy accretion in rats. Journal of Nutrition 123, 21092114.

Suárez A, Ramírez MC, Faus MJ \& Gil A (1996) Dietary longchain polyunsaturated fatty acids influence tissue fatty acid composition in rats at weaning. Journal of Nutrition 126, 887-897.

Sztalryd C \& Kraemer FB (1994) Differences in hormone-sensitive lipase expression in white adipose tissue from various anatomic locations. Metabolism 43, 241-247.

Wieland O (1957) Eine enzymatishe method zur bestimmung von glycerin (An enzymic method for the determination of glycerol). Biochemical Zeitung 239, 313-319.

Zinder D \& Saphiro B (1971) Effect of cell size on epinephrineand ACTH-induced fatty acid release from isolated fat cells. Journal of Lipid Research 12, 91-95. 